Canadian Journal of Higher Education Revue canadienne d'enseignement supérieur

Volume 42, No. 3, 2012, pages 1-23

\title{
The Making of a Policy Regime: Canada's Post-Secondary Student Finance System Since 1994
}

Richard Wellen, Paul Axelrod, Roopa Desai-Trilokekar, \& Theresa Shanahan York University

\begin{abstract}
This paper examines the pattern of decision-making, lobbying, and influence that led to the landmark series of federal student assistance policies introduced by Jean Chrétien's Liberal government in the late 1990s. The package of new initiatives-dubbed the Canada Opportunities Strategy-not only partially reversed an earlier period of fiscal restraint but also brought a new emphasis on direct forms of student assistance such as grants, bursaries, and tax credits. However, programs such as the Canada Millennium Bursaries and the Canada Education Savings Grants, despite their focused approach and innovative structure, came to be regarded as weak policy tools when measured against their ostensible goals of widening access to post-secondary education and efficiently targeting student assistance on the basis of need. The new policy regime also failed to fulfil nearly two decades of previous efforts by policy-makers to transform Canada's student debt program into a systematic income-contingent loan program. We offer explanations of this pattern of policy inconsistency and incoherence by examining the awkward challenges of intergovernmental relations in the Canadian federal system as well as the fragmentation and competing goals now evident in student assistance policy networks. We contrast the student finance policy regime with the arguably more coherent set of research and innovation policies established by the federal government during the same period. We use policy network analysis as our theoretical framework, and we use data from our extensive interviews with higher education stakeholders and policy-makers to provide empirical support.
\end{abstract}




\section{RÉSUMÉ}

Cet article analyse les processus décisionnels, les actions des groupes de pression et leur influence qui ont mené à une série de dispositifs législatifs quant à l'aide financière aux étudiants introduits par legouvernement libéral de Jean Chrétien à la fin des années 1990. Cet ensemble d’initiatives appelé « la stratégie canadienne pour l'égalité des chances » a non seulement mis fin (partiellement) à une période de restriction fiscale, mais a également conduit à une aide directe aux étudiants sous forme de subventions, de bourses et de crédits d’impôt. Malgré leurs approches ciblées et leurs structures innovatrices, des programmes tels que les Bourses canadiennes du millénaire et la Subvention canadienne pour l'épargne-études furent considérées comme des moyens peu efficaces face aux objectifs ambitieux d'élargir l'accès à l'éducation postsecondaire et à fournir une aide adéquate basée sur les besoins financiers des étudiants. De plus, ce nouveau régime a été incapable de mener à terme d'anciennes politiques entreprises près de vingt ans plus tôt visant à transformer le programme canadien de dette étudiante en programme de prêts conditionnels aux revenus. Nous expliquons l'inconsistance et la contradiction de cette politique par l'analyse de l'effroyable défi que présentent les relations intergouvernementales dans le système fédéral canadien ainsi que la diversité et la compétitivité des objectifs dans les réseaux d'assistance aux étudiants. Nous mettons en opposition le système d'aide financière aux étudiants avec une autre politique plus cohérente portant celle-ci sur la recherche et l'innovation établie par le gouvernement fédéral durant la même période. Notre cadre théorique s'appuie sur les outils d'analyse des politiques publiques, ainsi que les données provenant d'une longue série d'entretiens avec les parties concernées par l'éducation postsecondaire et des personnes responsables de politiques publiques afin de profiter de leur perspective empirique.

By the early 1990 s the nature and structure of student assistance in Canada's post-secondary education system had begun to matter a great deal to decision-makers and members of policy communities. Years of federal funding restraint meant that tuition increases were outpacing inflation in most provinces, and student debts were rising. By the end of the decade, reductions in federal transfers to the provinces were succeeded by policies that provided significant new resources in a repackaged form. This situation marked a culmination of 30 years of attempts by governments, lobbyists, university elites, and federal and provincial commissions to redefine the federal role in post-secondary support for institutions, researchers, and students alike. Many of the key initiatives in this process are discussed below and summarized in Table 1 . The policies that were eventually adopted by Jean Chrétien's Liberal government-and corresponding shifts in provincial policies-increased the federal share of spending on student assistance from close to one-half to more than two-thirds of the total in most provinces (Junor \& Usher, 2007, pp. 8-33). The new support took the form of direct transfers to individuals who were bearing the cost of higher tuition. This paper sheds light on the policy-making process responsible for the formation of the student financial assistance system that took shape during these years. 
Table 1.

Selected Policy Highlights in Federal Student Assistance Policy

1984-1992

Income Contingent

Loan (ICL) Proposals

1994

Response to the Liber-

al's social policy review

1995-1997

Liberals cut transfers to

provinces

1997

Report: Renewing

Student Assistance in

Canada

1998

Canadian Opportunities

Strategy

1999-2008

The rise and fall of the

Canadian Millennium

Scholarship Foundation
In the wake of fiscal restraint in the 1980s, a series of federal and provincial commissions recommend that students should pay more for post-secondary education. The Bovey Commission (1984) in Ontario and the Smith Commission (1991) reporting to the Association of Universities and Colleges of Canada (AUCC) recommend that some of the money be leveraged from students by offering them loans with "income contingent repayment" (ICR) provisions.

Lloyd Axworthy's social policy Green Paper advocates income contingent loans, higher tuition, and reduced federal transfers. These proposals prompt strong student opposition led by the Canadian Federation of Students. The document fails to find support from other stakeholders as well.

Federal Finance Minister Paul Martin announces unprecedented cuts to intergovernmental transfer payments. These cuts lead to a legacy of higher tuition fees for students and reduced operating grants for post-secondary institutions.

As the federal deficit is eliminated earlier than planned, student assistance stakeholders unify to recommend a package of new measures to help students absorb cost of higher education. This report is issued by the AUCC and includes participation by two rival groups, the Canadian Federation of Students and the Canadian Alliance of Student Associations.

In its 1998 budget, Chrétien's federal government announces the formation of the Canada Millennium Scholarship Foundation (CMSF) and the Canada Education Savings Grant program (CESG). The first program provides bursaries and the second rewards families who contribute to Registered Education Savings Plans (RESPs).

A report by the Auditor General (2009) raises concerns about the apparent lack of accountability of the CMSF as an autonomous publicly endowed foundation. This report is succeeded by criticisms regarding the CMSF's program design and its status as a "legacy program" for Prime Minister Chrétien. The CMSF is replaced in 2008 by the Canada Study Grants Program (CSGP).

The literature on student assistance in Canada has grown enormously in the last decade, largely in response to the aforementioned transformation in policy and the policy environment (Anisef \& Sweet, 2005; Finnie, Sweetman, Meuller, \& Usher, 2008). The goal of nearly all of this literature, quite understandably, has been to provide evidencebased discussion and analysis to inform normative or political debate about policies related to accessibility, tuition, student assistance, and loans. Indeed, the question of the legitimacy and effectiveness of current post-secondary student funding and participation policies has acquired a higher profile both within government and in the larger society. The reasons for this development include increased participation rates, the acknowledged impact of higher education as both an economic instrument and an instrument of social 
equity (Jones, Shanahan, Padure, Lamoureux, \& Gregor, 2007; Wellen, 2004), and social and ideological struggles around the changing role of the state in social provision.

In this paper we do not attempt to provide a normative assessment of key elements of the current policy system such as the introduction of higher fees or the delivery of more student assistance in the form of universal rather than needs-based benefits. Instead, we are interested in posing the question of how and why the current system came about and why these policies and policy delivery instruments took the form they did. Why did policy-makers come to favour direct transfers to students over support for institutions? What accounts for the stronger role of the federal government in designing the policy regime of student support? Were these policies simply part and parcel of the larger trend toward targeted and conditional funding, the most prominent of which were new programs to support research and innovation in universities (Axelrod, Desai-Trilokekar, Shanahan, \& Wellen, 2011; Fisher et al., 2006)? Why did so many members of the policy communityinside and outside of government-support the adoption of a universal income-contingent loan system, yet fail repeatedly to implement one? Why did policy-makers reserve such a large role for tax and savings credits that are not targeted to help students in need (Junor \& Usher, 2007) despite the universally shared assumption within policy networks that higher fees require focusing proportionately more aid on needy students?

To answer these questions we have conducted dozens of semi-structured interviews with policy insiders and advocacy groups. Much of our data has been obtained by interviewing significant members of the post-secondary policy community who have been involved in the policy-making process, as civil servants, members of the legislature, or leaders of major stakeholder constituencies or organized interest groups (including lobbyists, university presidents, and others in the community). These interviews reveal a great deal about how policy decisions are made within governments, how participants in policy networks have been able to influence those decisions and their implementation, and which stakeholders have been able to win favourable policies, and why.

Just as importantly, we have tried to employ these data to test the applicability of some of the leading frameworks for understanding public policy offered in the political science and policy analysis literature. ${ }^{1}$ In particular, we have used our interviews as tools to assess the relative role of interests, institutions, and ideas in the policy-making process (Hall, 1998). We offer some suggestions about how the interaction between institutions of Canadian federalism and the specific characteristics of policy networks and communities might explain policy outcomes. Policy network theory is particularly valuable here because it attempts to understand the complex relationship of societal actors to the governance structures of the state (Tapper, 2007). Policy network analysis is also flexible enough to show how many different kinds of variables-macro-political as well as specific network characteristics-bear upon the policy-making process and help determine policy outcomes (Atkinson \& Coleman, 1992). As we shall show, the role of ideas and the conflict among ideas are also very important. For example, the major organized student and faculty groups in Canada treat post-secondary education as a public good and a vehicle of social equity. On the other hand, industry, governments, and key post-secondary elites such as university presidents are more willing to see the knowledge society as a field of economic opportunity where university graduates are the beneficiaries of private returns and universities themselves merit public and private support for their wealth-enhancing 
contributions. Initiatives around student fees have been strongly influenced by ideas, interests, and partisanship, but this influence has also been mediated by structural forces such as institutions and networks. An advantage of bringing in the analysis of structures and institutions is that we can more adequately account for the diversity and variability of modes of governance across policy domains or in the same policy domain across different states (Atkinson \& Coleman, 1992 Skogstad, 2005). Indeed, it may help us explain why similar configurations of ideas and interests in policy domains in different countries have not led to policy convergence. A good example of this diversity is the adoption of a comprehensive and universal income-contingent loan system in England but not in Canada despite active student opposition in both countries.

\section{BACKGROUND}

Because Canada's constitution assigns responsibility for education to the provinces, the development of federal support for post-secondary education (PSE) must be seen as a complex matter of history and politics (Cameron, 2005; Fisher et al., 2006). By 1967, the earlier system of federal direct grants to universities was absorbed into an intergovernmental fiscal transfer though which money intended for PSE was conveyed to provincial coffers with no strings attached, thereby leaving universities vulnerable to changing provincial-level priorities (Cameron, 2004). The fiscal transfer has taken on several incarnations since 1967, the most important being the Established Programs Financing (EPF) system beginning in 1977 whereby post-secondary support was packaged together with federal health care funding into a system of block transfers to provinces. Under the Progressive Conservative government of Brian Mulroney (from 1984 to 1993), these transfers were regularly subjected to caps that kept increases well below the level needed to cover rising costs related to inflation and the increased post-secondary enrolments and participation rates of the 1980 s. During this period, provincial governments, institutions, and students assumed increased financial burdens, a situation that prompted governments at all levels to look for new ways to fund higher education.

As we have explained elsewhere in greater detail (Axelrod et al., 2011), the landscape for post-secondary finance, and the priorities shaping higher education in general, shifted considerably by the middle of the 1990 s when the Chrétien-Martin Liberal government slashed federal transfers to the provinces in an attempt to confront the country's unprecedented annual deficits and levels of accumulated debt. Before these fiscal austerity measures, however, a significant battle over fees and new models of student debt had already taken place. In fact, in the early 1980 os two reports were commissioned by the federal and Ontario governments respectively, each of which recommended more flexible tuition fee policies. They also explored ways of making rapidly expanding post-secondary systems less reliant on government grants and ways of producing greater differentiation among institutions. At the federal level, the wide-ranging and influential Royal Commission on the Economic Union and Development Prospects for Canada (the MacDonald Commission) called for the reduction of intergovernmental transfers for post-secondary education. Reporting to the federal government on the challenges facing the national economy, the MacDonald Commission proposed the introduction of more direct support for students-perhaps in the form of vouchers-to offset the resulting higher fees; it also urged that fees be deregulated (Royal Commission, 1985). The Bovey Commission, reporting on 
Ontario's university system in 1984, proposed an Income Contingent Repayment (ICR) student loan plan that would link repayment to income after graduation and be accompanied by rising (though not deregulated) fees. The Bovey Commission was able to win support for this idea from a variety of sources across the political spectrum, including several academics, particularly economists, as well as the Ontario Federation of Labour. ${ }^{2}$

Although neither of these recommendations came to fruition during the Mulroney period, by the time Jean Chrétien's Liberals had taken power in 1993, the idea of ICR had been resurrected. Canada was a recession-weary country, sensitive to global competitive pressures and facing a period of fiscal restraint. For student finance issues, these conditions lent legitimacy-in Canada and other hitherto low-tuition countries-to the idea that the users and beneficiaries of post-secondary education should pay an increasing share of the costs (Chapman, 2005) so long as the new funding framework could assure accessibility for all qualified and eligible applicants by targeting assistance where it was most needed. The issue of post-secondary student finance, and especially rising student debt, had become a significant topic on the editorial pages of Canada's most widely read newspapers. The editors of the Globe and Mail were now avid and outspoken advocates of a system that would combine ICR loans with higher fees and grants targeted at students most in need (Higher Tuition, 1995; Why Higher Tuition, 1992; Why Universities, 1990). By 1991 the NDP was in power in Ontario and had received advice from the Council of Ontario Universities (COU) urging the adoption of an ICR plan as a way of providing new funds for colleges and universities. In the same year the Association of Universities and Colleges of Canada (AUCC) had heard similar recommendations from a commission it appointed which was headed by Stuart Smith, a former Ontario provincial politician and recent chair of the Science Council of Canada. The Smith Commission (1991) made a series of critical recommendations on topics as diverse as access, fees, the creeping prioritization of research at the expense of teaching, institutional autonomy and accountability, and credit transfers. The following year the AUCC struck a task force composed of eight influential university presidents to formulate a response to Smith's critical recommendations. In a carefully worded statement, the task force agreed that students should pay more and that an ICR loan system was worth exploring as a way of ensuring that access was not compromised by higher fees. But the task force added the proviso that "any gains universities make through tuition increases must not be neutralized by a reduction in government support" (Armstrong et al., 1992). This statement would prove to be a significant indication of how far universities themselves would be willing to bend to support government initiatives to change university financing and student assistance.

Income contingent loans were at the centre of a social policy review conducted by Human Resources Development Canada (HRDC) Minister Lloyd Axworthy for the new Liberal government in 1994. The plan was briefly outlined in an exploratory policy document that came to be known as the Green Paper. According to the document, the goal of the policy would be to "replac[e] the declining cash transfers [roughly $45 \%$ of federal transfers for PSE] over the coming years with more stable alternative forms of support that would help Canadians to borrow and save to get the higher education they need" (HRDC, 1994, p. 12). In the next section of the document, Minister Axworthy made the mistake of signalling surprisingly clear expectations regarding tuition fees: 
It is true that replacing federal cash transfers would put upward pressure on tuition fees. This may be a necessary price to pay to put in place a permanent system for ensuring accessibility to post-secondary education. Continuing with the existing course would see the cash transfers disappear over the coming decade, with tuition fees continuing to rise, but with no mechanism to sustain broad accessibility for Canadians (p. 12).

The Canadian Federation of Students (CFS) and other groups mobilized very successfully in an attempt to thwart Axworthy's initiative, which, they feared, would serve as a lever for tuition increases (Greenspon \& Wilson-Smith, 1996). The goal of the CFS and other activists and students on the left was to protect Canadian students from higher debt and the financial hardships that would follow from higher tuition. The CFS, for its part, continued to propose a reduction to tuition fees and a return to non-repayable grants for low-income students, a type of assistance that had been clawed back earlier in the decade in most provinces (Conlon, 2005). A rival student group-the Canadian Alliance of Student Associations (CASA) - was formed during this period, largely due to internal political divisions within the CFS, but also because it reflected pockets of student support for policies, such as ICR, that did not imply fee reductions (anonymous interviews).

According to a number of observers and interview respondents, the student protests were enormously effective in forcing the government to back down, but others maintain that serious concerns and reservations on the part of other influential players played an important role as well. Even to more sympathetic stakeholders, the Axworthy plan was perceived as vague and ill-informed, especially in light of its failure to clarify potentially controversial details such as interest subsidies and repayment thresholds (anonymous interviews). According to one former government insider, the weakness of the proposal may have been a result of the fact that the policy review itself was developed almost exclusively-and too hastily-at the political level, without sustained involvement by the bureaucracy within HRDC (anonymous interview). Robert Best, former vice-president of national affairs at AUCC, noted in an interview that universities lacked unanimity about the merits of ICR loans. Consistent with its earlier response to the Smith report, the AUCC was concerned about the possibility that federal cash transfers would be dropped altogether (Robert Best, interview, August 20, 2009). Others report that there was some suspicion within provincial governments that the high initial cost of the program might land on their laps (anonymous interview). Provinces may also have been alarmed that the document anticipated steep increases to tuition which, unlike student assistance, falls exclusively under provincial jurisdiction, a point that one influential post-secondary leader said would have raised a red flag, especially in Quebec (anonymous interviews; Robert Best, interview, August 20, 2009).

The ultimate failure of the Axworthy initiative meant that any systemic attempt to reform federal student assistance would have to be revisited later, by which time the country's enormous fiscal hole would be addressed and a solution more compatible with Canada's political institutions and federal makeup might be found. In the meantime, cuts to federal transfers were creating a lasting legacy. It has been estimated that, from 1995 to 2005, the amount of the Canada Health and Social Transfer (CHST) that went to fund PSE institutions declined by 50\% on a per student basis (Jones et al., 2007). By 2009 
government funding was providing only $55 \%$ of the operating revenue of colleges and universities, which was down from the 70\% figure of the mid-1990s (Robertson, 2003). The impact on the provinces and students might have been worse had the federal government followed through on an inchoate plan to unload full responsibility for student loans onto the provinces (Robert Best, interview, August 20, 2009; Usher, 2010). In the end, most provinces-while maintaining regulatory authority over most kinds of undergraduate fees-allowed institutions to raise tuition to make up for the shortfall in operating revenues. Between 1991 and 2006, the average undergraduate tuition in Canada more than doubled in inflation-adjusted terms. By the end of that period, average annual undergraduate fees stood at $\$ 5,138$, though there was considerable variability among provinces and growing pockets of tuition deregulation, especially in the case of professional programs and some graduate programs (Statistics Canada, 2007). Tuition increases contributed to the doubling of student debt over the course of the 1990s (Baldwin \& Parkin, 2007).

\section{FRAMING THE CANADIAN OPPORTUNITIES STRATEGY}

The fiscal restraint of the mid-1990s did not signal the end of federal support for student assistance. Aided by economic recovery and lower interest rates, a somewhat surprised Liberal government was running a surplus by 1997 (Scott Clark, interview, August 20, 2009). Rather than restoring intergovernmental transfers to their previous levels, the government decided to emphasize other channels and instruments for supporting post-secondary institutions. The vehicles chosen were not unlike those recommended by the MacDonald Commission more than a decade earlier: improved financial assistance and loans to students, tuition-offsetting tax credits for current students, savings grants for the families of prospective students, and strategic funding to support the activities of researchers and research infrastructure (Fisher et al., 2006).

Most significantly for our study, virtually all of the measures affecting student finance reflected priorities that were agreed to in a series of roundtable meetings held among several stakeholder groups convened by the AUCC. The seven groups invited included university financial aid officers, community colleges, the Canadian Association of University Teachers (CAUT), and both the CFS and CASA. As we have explained elsewhere (Axelrod et al., 2011), it is especially notable that the two rival student groups could suspend many of their differences for the purpose of achieving common ground on student assistance at a time of fiscal upheaval and a lack of clear direction and initiative from within government. Alex Usher, former national director of CASA who had become an adviser to the AUCC at the time of these roundtable discussions, recounts that the groups were able to seize the opportunity of leveraging recent publicity about rising student debt, which had become a "big tent" issue (Usher, 2010). The roundtable took place under the leadership of Robert Giroux, executive director of the AUCC and a respected former civil servant who was both well-connected in Ottawa and who knew the intricacies of the federal budget process (anonymous interview). Giroux (along with several university presidents) was also invited to sit on a special government advisory committee on post-secondary issues while working for the influential lobby group. This group had already won the commitment of the finance minister to a research and innovation agenda which would later lead to the formation of the Canadian Foundation for Innovation and the Canada Research Chairs program (Axelrod et al., 2011). Given these factors, including Giroux's more pro- 
fessional approach to lobbying, and the unusual concordance of views in the sector, the exercise exuded credibility and a prospect for success. In January 1997 the AUCC released a summary report, entitled Renewing Student Assistance in Canada, which proposed a series of measures to deal with the new challenges of student assistance in Canada. These challenges included tax deductions for families and individuals saving for post-secondary education, interest relief for graduates who had difficulties repaying student loans, and restoration of non-repayable grants (AUCC, 1997; Usher, 2010).

When the government announced the Canadian Opportunities Strategy (COS) in the budget presented to Parliament in February 1998, it included policies addressing all of the major priority areas identified in the AUCC report. Although the policies themselves were finally developed among a network of key officials clustered in the Department of Finance and the Prime Minister's Office, the cooperation, interaction, and feedback between state and non-state actors were crucial to their formulation. Three noteworthy components of this plan were interest relief on student loans; the establishment of non-repayable need-based assistance through the Canada Millennium Scholarship Foundation (CMSF), which had been announced earlier in the government's Speech from the Throne; ${ }^{3}$ and the introduction of the Canada Education Savings Grants (CESG). We will consider each of these briefly in turn.

\section{Interest Relief and Student Loans}

Between 1993 and 2003, the period during which the steepest tuition increases occurred, the percentage of students who received loans or bursaries from all government programs jumped from $34 \%$ to $54 \%$ (Andres \& Adamuti-Trache, 2008). As a result of the COS, more students were also eligible for income-related interest relief on their student loans. In addition, the period for receiving interest relief was increased to almost five years. The result was that by $2004,12 \%$ of borrowers were taking advantage of interest relief, though it is estimated that well under 50\% of those who would be eligible for such relief successfully accessed this assistance (Situ, 2006). Tax deductibility on interest paid on student loans was also introduced. The student assistance roundtable group had called for robust measures, such as deferred grants, that would "link more closely an individual's repayment obligations with their ability to repay" (AUCC, 1997). Although the measures that found their way into the 1998 budget introduced a certain degree of income contingency for loan repayment, a more recent program introduced by the Conservatives in 2009 now provides more substantial loan forgiveness for low-income borrowers after graduation. Loan forgiveness effectively targets assistance at needy graduates, but its effectiveness in improving access, like that of any single instrument, is subject to question. Most notably, Canada still lacks a universal ICR plan comparable to what was envisaged in the 1994 Green Paper or what can be found in a jurisdiction like England where any student may choose to defer payment of fees-and now living costs-until his or her post-graduation income reaches US\$32,000. Indeed, the highly controversial 2011 tuition reforms recently implemented in the United Kingdom in the face of mass protests has shown that a comprehensive universal ICR program can be used to pave the way for large tuition fee increases, which, in this case, will not only shift the balance of private and public funding but also likely lead to further, market-driven stratification among universities. ${ }^{4}$ 


\section{Tax Credits, Savings Grants, and Universal Student Assistance}

The Liberal government brought in significant increases to education tax credits for students enrolled in post-secondary studies in the period leading up to and including 1997. By 2007 the typical Canadian post-secondary student (or his or her family) could expect to receive education, books, and tuition tax credits of approximately $\$ 2,000$, which is close to $40 \%$ of the typical annual tuition bill, depending on the province of residence or enrolment (Berger, 2009 Neill, 2007). These tax credits are available to all students, regardless of need or income, but they can only be claimed in the current year by students with income or by students whose parents foot their tuition bill. Their effectiveness has been questioned because they do not relieve the burden of paying upfront cost, and they are neither transparent nor palpable until they are calculated much later when tax returns are filed (Motte, Berger, \& Parkin, 2009).

One of the highlights of the 1998 Canadian Opportunities Strategy was the introduction of the Canada Education Savings Grant (CESG), another benefit available to all students regardless of need. This program provided a very significant savings incentive for families of prospective post-secondary students who were now allowed to save up to $\$ 4,000$ a year in the tax-exempt Registered Education Savings Plan (RESP), a change that gave new life to this previously little-used savings vehicle. Beneficiaries were provided with a $20 \%$ matching government grant on the first $\$ 2,000$ (now $\$ 2,500$ ) of savings each year, which could amount to $\$ 7,200$ of matching federal money for each prospective student by the time of his or her $18^{\text {th }}$ year. The origins of the program illustrate the extraordinarily important role that the Department of Finance had come to play in the making of post-secondary policy. Key political advisers to Finance Minister Paul Martin had become convinced that the pressure of post-secondary education costs was becoming a serious issue for middle-class families. The AUCC student assistance coalition had already recommended the parallel idea of making RRSP contributions tax-deductible, but in its final report the group assigned a much higher priority to debt relief for students than to tax incentives for families saving for education (AUCC, 1997a; AUCC, 1997b). By contrast, highly visible direct grants to post-secondary education savers became a priority for the political staff in the Department of Finance. The department's bureaucrats believed the proposed CESG was an unwise use of the tax system, and there was considerable debate within the Department of Finance about whether a savings top-up as high as 20\% would crowd out RRSP retirement savings (anonymous interview; Martin, 2008). The political staff won the day when focus groups showed that a $20 \%$ matching grant would be needed to leverage savings from entire extended families and breathe new life into the RESP. The grant would also provide additional encouragement for the major private sector financial institutions to expand their participation in the RESP program (anonymous interview; Martin, 2008).

The CESG has been frequently criticized on the grounds that it is skewed heavily toward those students whose families can afford to undertake a long-term savings program for post-secondary education and because it provides assistance primarily to those who would attend post-secondary studies without it (Junor \& Usher, 2007). From 1999 to 2009, $\$ 4.75$ billion was spent on the CESG, whereas the need-based Millennium bursaries over the same period totalled approximately $\$ 3.5$ billion (CFS, 2009). Nevertheless, 
the federal government defends the program on the grounds that it serves an unmet need, namely, to encourage families to engage in a long-term financial plan to facilitate their children's future higher education rather than simply providing assistance at the time of entry into post-secondary studies (HRSDC, 2003). ${ }^{5}$

\section{The Canadian Millennium Scholarship Foundation}

Announced earlier in the Throne Speech, the 1998 federal budget established the Canadian Millennium Scholarship Foundation (CMSF) as an independent foundation to administer a $\mathrm{C} \$ 2.5$ billion 10-year endowment which would provide over $\mathrm{C} \$ 250$ million a year in need-based grants or bursaries. Ultimately, this allocation sought to address the concerns of student groups who had lamented the gradual phase-out of need-based, non-repayable grants in favour of loans over the earlier part of the decade. Our interviews suggest that the issue of brain drain and attracting "stars" was gathering political steam in higher education at this time. This discourse influenced early discussions around the creation of the CMSP insofar as the government initially talked about establishing a scholarship program to attract "the best and brightest." However, they soon realized, after consulting with university leaders, most notably UBC President Martha Piper, that the need lay not with the very exceptional students who had received more funding than they needed but elsewhere with regular "good students." Thus the policy-makers were persuaded that the program should focus instead on "students that were intellectually able to get into university but financially needed help" (anonymous interview). The shape of the CMSP thus shifted from a purely merit-based scholarship program for star students toward a mix of merit and need-based scholarships and bursaries. This change in focus is significant in terms of policy-making because, arguably, consultation with the university leaders shifted the fundamental objectives and shape of the program to address access and debt repayment.

Consequently, a key policy goal of the CMSF became one of responding to the especially salient issue of student debt. Such a program would not only help needy students, but presumably also the prime minister who saw this program as a legacy initiative and part of his government's package of "knowledge society" programs. Some critics have charged that the CMSF was an unaccountable "boutique" program. This criticism followed earlier concerns that the use of such autonomous policy instruments made it more difficult to ensure accountability in the expenditure of public funds (Office of the Auditor General, 1999). Other critics have argued that because the CMSF bursaries had to be directly disbursed to students, they merely displaced pre-existing student assistance programs at the provincial level (Bakvis, 2007). Sources close to the program readily admit that displacement occurred, largely because the bursaries reduced the neediness of the same recipients who would otherwise benefit from need-based aid administered at the provincial level (anonymous interview). The goal of the early directors of the CMSF was to manage this displacement. Special arrangements had to be negotiated with each province to ensure provincial money that was freed up would remain in the post-secondary sphere in a way that would benefit students, thereby meeting the objectives of the CMSF.

A 2003 report on the performance of the CMSF conducted by political scientists at Queen's University concluded that much of the provincial-level spending freed up by the CMSF's grants flowed into debt reduction programs for graduating students rather than 
into access-enhancing initiatives for the neediest students (Institute of Intergovernmental Relations, 2003). People close to the now-defunct program readily admit that this narrow bias in favour of debt reduction was inevitable given the exceedingly complex challenges of addressing the social barriers to improving access (through early outreach, for example) and also in light of the political importance of student debt at the time when the CMSF's programs were initially designed. Indeed, as one anonymous respondent argued, the very legislation that created the CMSF was flawed because it only allowed funds to be given to those who were already enrolled in - or accepted to - post-secondary institutions.

More than any other component of the Canada Opportunities Strategy, the history of the CMSF was marked by political contention between levels of government, competing visions of Canadian federalism, and rivalry among interest groups and government departments. A number of provinces, especially Quebec, were not pleased with the new level of intrusion into their jurisdiction over post-secondary education. Indeed, officials from the Quebec government actually refused to speak directly with officers of the CMSF (Cameron, 2010). People close to the program saw the choice to develop a new federal instrument for delivering student assistance as another episode in the national unity struggles between a strongly federalist prime minister and the separatist government of Quebec. The Ontario government, according to a highly placed official, also came to resent the sudden appearance of a new federal initiative that had been hatched without the knowledge of the province and would overlap with a student grant program that was already under development to address rising fees (anonymous interview). Groups such as CFS and CAUT, which were the leading organized lobbying interests for student assistance, became strong opponents of the CMSF despite their earlier participation in the student assistance coalition of 1997. Old rivalries in the student movement were revived as Alex Usher, the former leader of CASA and nemesis of the CFS, was named as the CMSF's Director of Research and Program Development. In the end, however, the very fact that CMSF operations and governance were independent of the federal government arguably allowed it some freedom from politics and gave the CMSF's officers greater scope to be flexible and innovative in negotiations with provinces (Cameron, 2010). As a result, the provinces ultimately came to accept the program. ${ }^{6}$ Ironically, however, tensions developed between the autonomous foundation and the federal government. In the words of one insider, HRSDC, the department responsible for the Canada Student Loan Program, saw itself as a competitor with the self-governing foundation (anonymous interview). Indeed, consultants hired by HRSDC to review the CMSF in 2007 suggested that if it were renewed for a second mandate, the CMSF should be required to report directly to a minister (Samson and Associates, 2007)..$^{7}$ One of the most interesting and lasting legacies of the CMSF was the expenditure of \$55 million on widely disseminated and influential research into student access. ${ }^{8}$ This ambitious and unanticipated expenditure was approved by its board of directors apparently because it became convinced that, without a better understanding of the barriers to access, the resources of the CMSF would be spent blindly (anonymous interview). The research became notable for its preoccupation with identifying and defining the complex mix of financial and non-financial barriers to access and the examination of those factors that could be influenced by social policy. The research also minimized the role played by higher tuition in impeding access to post-secondary education, prompting groups like the CFS to accuse the CMSF of being a partisan apologist for 
fee hikes and high student debt loads (CFS, 2007b). ${ }^{9}$ Harper's Conservative government announced the termination of the CMSF in the budget presented to Parliament in 2008. The program had little support inside and outside of government and, as an orphaned, autonomous product of a previous government, had little chance of surviving with its independence intact. Nevertheless, the strongest reason for its cancellation, according to sources connected with the program, may have been that the government could score political points in Quebec by putting an end to a legacy program for the former Liberal prime minister (anonymous interviews). The program was replaced by the Canada Student Grants Program (CSGP), which the CFS hailed as a lobbying victory (CFS, 2008). The program is run by HRSDC and disburses a similar total amount of non-repayable assistance, featuring slightly more grants in smaller amounts as compared to the former Millennium bursaries.

\section{UNDERSTANDING THE REFORIMS}

The reforms centred on the Canadian Opportunities Strategy (COS) have in some ways edged Canada closer to the "high tuition, high aid" policy regime more characteristic of its southern neighbour. ${ }^{10}$ The package of policies announced in 1998 was part of a shift in the composition of federal post-secondary funding in favour of targeted transfers and away from transfers to institutions. In 1994 targeted and conditional federal support for post-secondary education had been approximately equal to block transfers (at \$2.3 billion). Ten years later the level of targeted federal funding was more than twice that of block transfers (Junor \& Usher, 2007). From the standpoint of improving access or even helping needy students, there is evidence that the new transfers to individuals have not been targeted effectively. For example, in its final year the CMSF published a report showing that tax and savings credits, which primarily benefit middle- and upper-income groups, had doubled in the 10 years since 1998, while need-based aid had increased by only $20 \%$ over the same period (Motte et al., 2009). Although programs like the Millennium bursaries have helped to moderate the level of student debt, the problem of improving accessibility for lower-income Canadians has proven more difficult to address. A report published by CMSF at the end of its mandate noted that the post-secondary participation gap between the upper- and lower-income quartiles had actually widened between 1993 and 2006 (from 23\% to 31\%) (Berger, 2009). ${ }^{11}$ In the minds of many, the reforms adopted since 1998 have suffered from a lack of legitimacy and have invited serious questions about their effectiveness and coherence (Bakvis, 2008). One explanation for this outcome may be that the policy network that formed around these issues was not able to overcome the fragmentation of authority and policy space within government and among societal actors. At one pole of the post-secondary policy sphere are organizations like the AUCC, which has operated much like an industry association working cooperatively with government and playing a leading role within the policy community dealing with the administration and funding of universities. At the other pole are organizations like the CFS and CAUT, which have often been focused on broad social justice issues and oppositional politics in addition to representing the formal interests of their members. These groups do not enjoy the same respect within-or access to-government. The CFS in particular represents students who already have access to post-secondary education, and so the policy gains they are likely to win would take the form of limiting tuition increases and 
lowering student debt. On the other hand, it is true that the CFS and associated groups have played a role in preventing the establishment of a full-scale ICR system. Depending on one's point of view, this role may be counted a success because such a program likely would have led to even further reductions in government transfers and higher tuition, as now appears to be the case in Britain. Student groups such as CFS and CASA have been critical of the fact that the composition of student assistance is awkwardly balanced in favour of categories of support that are directed at less needy, middle-class students and their families. Nevertheless, it is hard to imagine that the removal of such subsidies could compete with tuition as a focus of aggressive lobbying and protest.

Some of our interviews suggested that in order to gain access to and respect from policy-makers interested organizations need to engage in genuine dialogue, propose workable alternatives, and thank government for its efforts on behalf of the relevant sector: "You have to align your arguments, lobbying, and efforts with their picture ... You've got to go with an agenda. You've got to go with ideas; you've got to help them solve their problems. You have got to work with them ... [and] you've got to persevere, you become respected just because you persevere" (anonymous interview). Accordingly, groups that criticize government policy and highlight government shortcomings might not make inroads to policy-makers. However, this is not to say that such groups have no influence, because they might make inroads instead with social media and public opinion, which in turn, can affect the direction of policy. In effect, they go around the policy-making gatekeeping bureaucrats, aiming for the decision-making elected politicians. We found that, in part, successfully influencing policy appears to lie not so much in the carrot or stick strategy of lobbyists (cooperative/respectful or oppositional/critical of government), but more so with the ability of various groups within the PSE sector to achieve consensus and agreement around issues and their positions when approaching government.

Likewise, in viewing the overall policy mix, rational choice theory would suggest that the government's concern to court insecure middle-class voters has played an important role, and our interviews with government insiders support this impression. As one former official remarked, “The question I used to ask is, 'Who speaks for access?' The colleges speak for colleges, the universities speak for universities, and student leaders speak for their constituency. Access is for the people who are not there; they're not on assistance. It's not clear who speaks for them." The middle-class bias of student assistance policy can therefore be explained by the specific characteristics of policy networks and communities as well as by a political economy analysis that helps us understand how social and economic interests bear upon the definition and determination of policy objectives. Turning once again to student loan policy, institutional factors have appeared to play the largest role. In particular, the development of a national universal ICR system faces the especially large institutional challenge of coordinating national loan coverage across provincial variations in tuition policy (Tupper, 2009). It is noteworthy that the only countries with a national universal ICR system are Australia, Britain (with the exception of Scotland), and New Zealand. Each of these countries has either a unitary (as opposed to federal) system of government or other jurisdictional arrangements whereby tuition policy is controlled by the same level of government that provides loans. Of course, in Canada, provincial coordination challenges are not insurmountable; on occasion the federal government has managed to coordinate province-by-province agreements as in the case of the CMSP. But 
such efforts can be complicated and thwarted when provincial jurisdictional struggles are added to a united opposition from multiple groups within the PSE sector, as was the case with ICR. In terms of successful policy-making and implementation, achieving a critical mass of consensus within the sector is an important first step to government coordination and implementation of policy.

In contrast to the piecemeal nature of student assistance policies, federal research policies since 1997 have displayed a remarkable degree of strategic coherence (Tupper, 2009). The presidents of Canada's major research universities and the AUCC itself attained a new level of access and integration with governmental processes at the federal level, and this achievement has allowed them to cooperate effectively to forge a new (and, to some, controversial) research and innovation agenda. Universities won major new federal programs such as the Canada Foundation for Innovation (CFI), which sponsors research infrastructure projects based in large part on industry-driven needs and the ability to secure matching funding from industry partners or provincial coffers. They also negotiated the establishment of the Canada Research Chairs (CRC) program, which directly allocates federal funding to institutions to hire outstanding scholars in areas in which universities have recognized strengths. These new programs were favoured by the largely uncontested presence of the federal government in the area of research, which is reflected in the first instance by the existence and legitimacy of the national granting councils. ${ }^{12}$

Although it is possible to argue that these federal research and innovation initiatives represent problematic instances of academic capitalism, or tools for stratifying universities (Metcalfe, 2010; Polster, 2002), it is nevertheless hard to discount their strategic success, especially in comparison to the less coherent and arguably inconsistent package of student assistance policies adopted since 1998. In an attempt to explain why the Millennium scholarship program became a mechanism for reducing debt rather than improving access, Alex Usher (interview, September 8, 2009) suggested that the program was designed and implemented very quickly without the scale of funding needed to address the access issue fully and effectively. Moreover, as a number of our respondents have pointed out, the program itself was motivated in part by Prime Minister Chrétien's desire to flex his federalist muscles after achieving a narrow referendum victory against Quebec sovereignists. This motivation stands in stark contrast to the policy formation process connected with the research and innovation agenda in which university elites played the role of policy intermediaries who were engaged as partners with government and who, with the exception of objections that Quebec officials expressed regarding the CFI, were less encumbered by federal/provincial tensions (Tupper, 2009). When the AUCC did lend its increasingly authoritative voice to the matter of student assistance reform, the organization took great pains to ensure that the reforms it supported were consistent with the goal of protecting or enhancing the revenue-generating capacity of post-secondary institutions.

The comparison between research and student assistance policies can tell us a great deal about the very different impact the institutions of Canadian federalism can have on two discrete policy domains (Bakvis, 2007; Tupper, 2009). As Bakvis (2007) points out, the primacy of the executive in the Canadian political system concentrates power in cabinet and the Prime Minister's Office so that there is a propensity for policy advice and advocacy to flow through informal and personalized channels and relationships. As a consequence, the system favours certain kinds of advocacy interventions, and often those with 
a more elitist character, over others. The federal government, in the absence of any direct or formal governance over post-secondary institutions, sought and received the advice and support of authoritative members of the sector who were especially interested in the research and innovation agenda and could pursue these issues through informal channels. One of our interview respondents working in advocacy indicated that the small size of the post-secondary sector also favours the importance of individuals and personalities. This observation suggests that the primacy of the executive level within Canadian federalism and the specific characteristics of the post-secondary policy domain have shaped policy outcomes. Post-secondary policy entrepreneurs and innovators found a welcoming home within the Chrétien-Martin Liberal government. Much of this responsiveness was due to the commitments and interests of the prime minister and his finance minister and also key members of their political staff. The resulting arrangements led to a renewal of support for the post-secondary sector, but in the case of student assistance reform, the very factors that brought new resources also encouraged piecemeal policies that were often at cross purposes and were arguably dictated by short-term political agendas. As one former Department of Finance official noted, "The whole history of these policies [education tax credits and savings grants] is of incremental add-ons without anybody taking a holistic view and asking whether they make any sense."

The structures of federalism help not only to explain the selective treatment of different kinds of interests and ideas, but also to clarify why intergovernmental transfers fell out of favour with the Liberal government. Indeed, our interviews show that both the prime minister and the finance minister felt that the federal government should pursue programs in a way that would allow it to take credit for post-deficit spending. As one post-secondary advocate recalled: "I remember being with [Finance Minister Paul] Martin at one point, saying, 'Why would I increase transfer payments so that Mike Harris, who was the premier of Ontario at that time, could cut taxes?' (anonymous interview). By concentrating on direct transfers to individuals and an arm's-length foundation with a limited-term endowment, the federal government chose policy instruments that would help it circumvent provincial authority in areas where its initiatives clearly occupied an area of overlapping jurisdiction. Indeed, a former key official in the Department of Finance insisted in an interview that the major student finance initiatives were planned with virtually no consultation with provincial governments. Although this approach enabled more federal funds to flow, it also limited the effectiveness of the programs because the federal government had to rely more on blunt policy instruments it could control, such as tax credits (anonymous interview).

\section{CONCLUSIONS}

We have sought to present an analysis that examines the complex mix of environmental and institutional variables in government and policy networks to help develop a fuller picture of how recent student assistance policies at the federal level have been made in Canada. Our hope is that this study will fill a number of gaps in current research which until now has been the preserve of those who are protagonists in policy debate, and for whom the key drivers of policies are ideas and the attempt to respond to macro-social or macro-economic factors. On the one hand, we do not want to deny that these factors are extremely important in explaining policy outcomes. For example, during the period 
under investigation, we cannot ignore the fact that post-secondary institutions were increasingly being valued for their economic function, and new ideas about the knowledge society and state provision were being articulated and embraced in Canada and elsewhere in response to global pressures. On the other hand, our analysis has allowed us to focus on the meso- and micro-level, where we can examine more closely the important role of institutions and the strategic interests and positions of particular groups or sets of actors. For example, the AUCC, which represents university and college executives, had once supported an ICR scheme that it believed would have yielded net funding increases for institutions. Support for the idea vanished following the perception that the Axworthy plan of 1994 would have simply replaced federal cash transfers with deferred payments by students with no clear prospect of increased funding.

Our focus on micro-political and institutional factors suggests potentially fruitful areas of comparative investigation as well. By studying policy network features and institutional structure, we have been able to offer explanations about the very different characteristics (and outcomes) in the two main federal higher education policy domains of research and innovation and student assistance respectively. Institutional analysis helps us highlight "path dependencies" (Schreyögg \& Sydow, 2009) to explain the significant policy differences among countries that otherwise have experienced many of the same challenges, conversations, and social, political, and economic pressures. It is notable that England has adopted a universal, systematic national ICR program, whereas Canada and the United States have not. This difference, arguably, says more about the difficulties of intergovernmental harmonization in a federal system as compared to the unitary system of government (as exists in the United Kingdom) than it does about any large differences in the political interests or normative assumptions driving the formation of the respective policy regimes. These and other comparisons show why it is important to support conceptual reflections on institutions and policy formation with the empirical investigation of specific policy domains and communities. The area of post-secondary education is a particularly fruitful and interesting area for such study because a great deal of policy capacity and mediation resides outside of the formal institutions of the state.*

\section{NOTES}

1. This research extends and deepens our parallel study of the governmental process (Axelrod, Desai-Trilokekar, Shanahan, \& Wellen, 2011).

2. The idea even won the support of some left-leaning academics (see Levin, 1990).

3. This speech, prepared by the government and delivered by the Governor General, outlines the government's agenda for the new session of Parliament.

4. The type of student assistance regime that a jurisdiction adopts has an impact not only on accessibility but also on the character of the post-secondary system and the differentiation of institutions within it.

5. This argument was part of the reasoning given in the AUCC-sponsored Round Table on Student Assistance (AUCC, 1997).

6. According to Bakvis (2008), provincial leverage over this program may have been partly because provinces controlled the front-line administration and much of the infrastructure of student grants and loans. 
7. The report accepted the argument that CMSF's arrangements with individual provinces ensured that net new funding was delivered to the post-secondary field, but it rendered no conclusion on "whether the joint efforts of the federal and provincial governments have met the needs of students and/or whether the aggregated assistance has increased or decreased, in relation to student needs, over the period of CMSF funding" (p. 34).

8. One source close to the CMSF called this "the biggest single investment of research on any social policy question in Canadian history, and one of the only to use truly experimental methodology."

9. Berger and Motte (2007), two researchers from the CMSF, argued that low socioeconomic status rather than tuition deprives individuals of the social and intellectual capital to access post-secondary education. Nevertheless, they wrote, "It would be wrong to conclude ... that because financial constraints are less important than other factors in explaining the enrolment gap, tuition could be left to rise or student financial assistance scaled back without consequence. The consequence presumably would be that financial factors would begin to account for a greater share of the enrolment gap between income groups.(43)"

10. An important difference is that a far greater proportion of student aid in the United States is supplied by the institutions themselves, and increasingly on the basis of merit.

11. By participation gap we mean the difference between the two socio-economic groups in percentage of 18- to 24-year-olds enrolled in post-secondary education.

12. The government of Quebec initially, though not ultimately, did object to the creation of the Canada Foundation on Innovation (Axelrod et al., 2011).

\section{REFERENCES}

Andres, L., \& Adamuti-Trache, M. (2008. University attainment, student loans and adult life course activities. In R. Finnie, R. E. Mueller, A. Sweetman, \& A. Usher (Eds.), Who goes? Who stays? What matters: Accessing and persisting in post-secondary education (pp. 239-277). Kingston, ON: Queen's School of Policy Studies.

Anisef, P., \& Sweet, R. A. (2005) Preparing for post-secondary education: New roles for governments and families. Montreal, QC: McGill-Queen's University Press.

Association of Universities and Colleges of Canada (AUCC). (1997a). Renewing student assistance in Canada: The student assistance reform initiative. Ottawa, ON: Author.

Association of Universities and Colleges of Canada (AUCC). (1997b). Renewing student assistance in Canada: The student assistance reform initiative. Ottawa, ON: Author.

Armstrong, R, Bazergui, A., Beachamp-Fortin, M., Davenport, P., Eliot, C. W. J., Hanen, M., ... Segal, B. (1992). Report of the AUCC task force on the Report of the Commission of Inquiry on Canadian University Education. Ottawa, ON: Association of Universities and Colleges of Canada.

Axelrod, P., Desai-Trilokekar, R., Shanahan, T., \& Wellen, R. (2011). People, processes and policy-making in Canadian post-secondary education, 1990-2000. Higher Education Policy, 24(2), 143-166. 
Bakvis, H. (2007) Contested federalism: certainty and ambiguity in the Canadian federation. Don Mills, ON: Oxford University Press.

Bakvis, H. (2008). The knowledge economy and post-secondary education: Federalism in search of a metaphor. In H. Bakvis \& G. Skogstad (Eds.), Canadian Federalism: Performance, Effectiveness and Legitimacy (pp. 205-22). Don Mills, ON: Oxford University Press.

Baldwin, N., \& Parkin, A. (2007). Canada's student financial aid system: The case for modernization. Policy Options, 28(10), 47-53.

Bellevance, J.-D., (2008, February 26). Ottawa mettra fin aux Bourses du millénaire. La Presse, p. A5.

Berger, J. (2009). Participation in postsecondary education: recent trends.In J. Berger, A. Motte \& A. Parkin (Eds.) The price of knowledge 2009 (pp. 27-62). Montreal, QC: Canadian Millennium Scholarship Foundation.

Berger, J., \& Motte, A. (2007). Mind the access gap: breaking down barriers to postsecondary education. Policy Options, 28(10), 42-46.

Berger, J., Motte A., \& Parkin, A. (2007). The price of knowledge 2006-07: Why access matters. Montreal, QC: Canada Millennium Scholarship Foundation.

Berger, J., Motte, A., \& Parkin, A. (2007). The price of knowledge 2006-07: Barriers to post-secondary education. Montreal, QC: Canada Millennium Scholarship Foundation.

Bovey, E. C. (1984). Ontario universities: Options and futures. Toronto, ON: Government of Ontario.

Cameron, D. M. (2001). Postsecondary education and Canadian federalism: Or how to predict the future. Canadian Journal of Higher Education, 31(3), 143-155.

Cameron, D. M. (2004). Collaborative federalism and postsecondary education: Be careful what you wish for. In C. M. Beach, R. W. Boadway, \& R. M. McInnis (Eds.), Higher education in Canada (pp. 205-228). Kingston, ON: John Deutsch Institute for the Study of Public Policy.

Cameron, D. M. (2005). Post-secondary education and research: Whither Canadian federalism. In F. Iacobucci \& C. Tuohy (Eds.), Taking public universities seriously (pp. 277-292). Toronto, ON: University of Toronto Press.

Cameron, D. S. (2010). A million futures: The remarkable legacy of the Canadian Millenium Scholarship Foundation. Vancouver, BC: Douglas \& McIntyre.

Canadian Association of University Teachers. (CAUT). (2007) Submission to the review of the Canada Student Loan Program. Retrieved from http://www.caut.ca/pages. asp?page $=620$

Canadian Council on Learning. (2010).Tallying the costs of post-secondary education: The challenge of managing student debt and loan repayment in Canada. Ottawa, ON: Author. 
Canadian Federation of Students (CFS). (2007a). Strategy for change: Money does matter, $5^{\text {th }}$ ed. Retrieved from http://www.cfsadmin.org/quickftp/Strategy_for_ Change_2007.pdf

Canadian Federation of Students (CFS). (2007b). Millennium Scholarship Foundation: A failed experiment in student financial aid. Retrieved from http://www.cfs-fcee.ca/ html/english/research/factsheets/factsheet-msf.pdf

Canadian Federation of Students (CFS). (2008). 2008 Federal budget analysis. Retrieved from http://www.cfs-fcee.ca/html/english/research/factsheets/Mem\%20 Adv-2008\%2obudget.pdf

Canadian Federation of Students (CFS). (2009). Registered Education Savings Plans: A national system of grants for the wealthy. Retrieved from http://www.cfs-fcee.ca/ html/english/research/factsheets/CFS-Fact\%2oSheet-RESPs.pdf

Chan, A. S., \& Fisher, D. (Eds.). (2008). The exchange university. Vancouver, BC: UBC Press.

Chapman, B. (2005). Income contingent loans for higher education: International reforms (Discussion paper 4091). Canberra, Australia: Australian National University Centre for Economic Policy Research.

Atkinson, M. \& Coleman, W. (1992). Policy networks, policy communities and the problems of governance. Governance, 5(2), 154-180.

Conlon, M. (2005). Income-contingent loans: Inequity and injustice on the instalment plan. Canadian Federation of Students Research Series. Retrieved from http://www.cfsfcee.ca/html/english/research/submissions/ICR-Inequality.pdf

Finnie,R., Sweetman, A. \& Usher, A. (2008). Introduction: A framework for thinking about participation in post-secondary education. In Finnie,R., Mueller, R., Sweetman, A. \& Usher, A. (Eds.).Who Goes, Who Stays, What Matters: Access to and Remaining in PostSecondary Education in Canada (3-32). Montreal. McGill-Queen's University Press..

Fisher, D., Rubenson, K., Bernatchez, J., Clift, R., Jones, G., Lee, J., ...Trottier, C. (2006). Federal policy and postsecondary education in Canada. Vancouver, BC: Centre for Policy Studies in Higher Education and Training.

Fisher, D., \& Rubenson, K. (2010). Canada. In D.D. Dill \& F. Van Vught (Eds.), National innovation and the academic research enterprise: Public policy in global perspective. Baltimore, MD: Johns Hopkins University Press.

Greenspon, E., \& Wilson-Smith, A. (1996). Double vision: The inside story of the liberals in power. Toronto, ON: Doubleday Canada.

Hall, P. A. (1998). The role of interests, institutions and ideas in the comparative political economy of the industrialized nations. In M. Lichbach \& A. S. Zucherman. (Eds.), Comparative politics: Rationality culture and structure (pp. 174-207). Cambridge, England: Cambridge University Press.

Higher tuition could mean better access. (1995, September 22). Globe and Mail, p. A16. 
Human Resources and Skills Development Canada. (HRSDC). (2003). Formative evaluation of the Canada Education Savings Grant Program. Ottawa, ON: Government of Canada.

Human Resources Development Canada (HRDC). (1994). Improving social security in Canada: A discussion paper. Ottawa, ON: Government of Canada.

Institute of Intergovernmental Relations. (2003). Canada Millennium Scholarship Foundation: Evaluation of the foundation's performance, 1998-2002. Kingston, ON: Author.

Jones, G., Shanahan, T., Padure, L., Lamoureux, S., \& Gregor, E. (2007). Marshalling resources for change: System level initiatives to increase accessibility to postsecondary education. Ottawa, ON: Canadian Milllenium Scholarship Foundation.

Junor, S., \& Usher, A. (2007). The end of need-based student financial information in Canada? Toronto, ON: Educational Policy Institute.

Levin, B. (1990). Tuition fees and university accessibility. Canadian Public Policy, 16(1), 51-59.

Martin, P. (2008). Hell or high water: My life in and out of politics. Toronto, ON: McClelland and Stewart.

Metcalfe, A. S. (2010). Revisiting academic capitalism in Canada: No longer the exception. Journal of Higher Education, 81(4), 489-514.

Motte, A, Berger, J., \& Parkin, A. (2009). Paying for post-secondary education. In A. Motte, J. Berger, \& A. Parkin (Eds.), The price of knowledge: Access and student finance in Canada ( $4^{\text {th }}$ ed., pp. 87-123). Montreal, QC: Canadian Millennium Scholarship Foundation.

Neill, C. (2007). Canada's tuition and education tax credits. Millennium Research Paper No. 30. Montreal, QC: Canada Millennium Scholarship Foundation.

Office of the Auditor General. (1999). Report to the House of Commons, November 1999. Ottawa, ON: Public Works and Government Services Canada.

Polster, C. (2002). A break from the past: Impacts and implications of the Canadian Foundation for Innovation and the Canada Research Chairs Initiatives. Canadian Review of Sociology and Anthropology, 39(3), 275-299.

Robertson, T. (2003). Changing patterns of university finance. Education Quarterly Review (Statistics Canada), 9(2). 9-18.

Royal Commission on the Economic Union and Development Prospects for Canada. (1985). Report. Ottawa, ON: Department of Supply and Services.

Samson and Associates. (2007). Value for money review of Canada Millennium Scholarship Foundation: Final report. Ottawa, ON: Human Resources and Skills Development Canada

Schreyögg, G. \& Sydow, J. (2009). Understanding institutional and organizational path dependencies. In G. Schreyögg \& J. Sydow (Eds.), The hidden dynamics of path dependence: Institutions and organizations (pp. 3-12). London, England: Palgrave Macmillan. 
Skogstad, G. (2005, June). Policy networks and policy communities: Conceptual evolution and governing realities. Presented at the meeting of the Canadian Political Science Association, University of Western Ontario, London, ON. Retrieved from http:// www.cpsa-acsp.ca/papers-2005/Skogstad.pdf

Shanahan, T., \& Jones, G. (2007). Shifting roles and approaches: Government coordination of post-secondary education in Canada, 1995-2006. Higher Education Research and Development, 26(1), 31-43.

Situ, J. (2006).Canada student loans repayment assistance: Who does and does not use interest relief? Culture, Tourism and the Centre for Education Statistics: Research Papers. No. 47. Ottawa, ON: Statistics Canada.

Slaughter, S., \& Leslie, L. (1997). Academic capitalism: Politics, policies and the entrepreneurial university. Baltimore, MD: Johns Hopkins University Press.

Smith, S. L. (1991). Report: Commission of inquiry on Canadian university education. Ottawa, ON: Association of Universities and Colleges of Canada.

Statistics Canada. (2007). Education indicators in Canada. Retrieved from http:// www.statcan.gc.ca/pub/81-582-x/81-582-x2007001-eng.htm

Sweet, R., \& Anisef, P. (2005). Preparing for post-secondary education: New roles for governments and families. Montreal, QC, and Kingston, ON: McGill-Queen's University Press.

Tapper, T. (2007). The governance of British higher education: The struggle for policy control. Dordrecht, The Netherlands: Springer.

Tupper, A. (2009). Pushing federalism to the limit: Post secondary education policy in the millennium. In G. B. Doern, Research and innovation policy: Changing federal government-university relations (pp. 35-59). Toronto, ON: University of Toronto Press

Usher, A. (2010). The importance of good data. Globe and Mail: Eye on Higher $E d$. Retrieved from http://www.globecampus.ca/blogs/eye-higher-ed/2010/o8/26/ importance-good-data/.

Wellen, R. (2004). The tuition dilemma and the politics of "mass" higher education. Canadian Journal of Higher Education, 34(1), 47-81.

Why universities should be able to raise tuition fees. (1990, October 9). Globe and Mail, p. A16.

Why higher tuition fees make sense. (1992, March 12). Globe and Mail, p. A14.

\section{CONTACT INFORMATION}

Richard Wellen

Faculty of Liberal Arts and Profesional Studies

York University

Toronto, Ontario $\mathrm{M} 3 \mathrm{~J}_{1} \mathrm{P}_{3}$

rwellen@yorku.ca 
Richard Wellen is Associate Professor in the Department of Social Science and the Graduate Programs of Social and Political Thought and the Faculty of Education at York University. His research interests include post-secondary policy, changing models of scholarly publication, the social responsibilities of universities, and contemporary political theory. He is the author of Dilemmas in Liberal Democratic Thought Since Max Weber.

Paul Axelrod, professor and former dean of the Faculty of Education at York University, is the author of numerous publications on higher educational history and policy development. His books include Scholars and Dollars: Politics, Economics and the Universities of Ontario, 1945-198o; Making a Middle Class: Student Life in English-Canada During the Thirties; The Promise of Schooling: Education in Canada, 180o-1914; and Values in Conflict: The University, The Marketplace, and the Trials of Liberal Education.

Roopa Desai-Trilokekar is currently Assistant Professor, Faculty of Education at York University. She has extensive professional experience in international and intercultural education in Canada, India, and the United States. Her research interests include federal and provincial government policy on internationalization, and she has edited the book Internationalizing Canada's Universities (with Adrian Shubert, York University, and Dr. Glen Jones, University of Toronto). Her research interests also include the internationalization of teaching and learning, student experiential learning through international education, and the internationalization of teacher education.

Theresa Shanahan is Associate Professor and Associate Dean, Research and Professional Development in the Faculty of Education at York University. Her research interests include education law and policy, the political economy of post-secondary education, university governance (system and institutional decision-making), professional education/ governance/ethics, human rights, and access and equity issues in education. She has authored numerous articles and national and international conference papers on higher education policy, legal education, and university and professional governanc 